Article

\title{
Social Impact of Farmland Abandonment and Its Eco-Environmental Vulnerability in the High Mountain Region of Nepal: A Case Study of Dordi River Basin
}

\author{
Suresh Chaudhary $1,2,3,4, *$ (D) , Yukuan Wang $1,3, * \mathbb{1}$, Narendra Raj Khanal ${ }^{5}$ (i) , Pei Xu ${ }^{1,3}$, \\ Bin Fu ${ }^{1,3}$, Amod Mani Dixit ${ }^{4}$, Kun Yan ${ }^{1,3}$, Qin Liu ${ }^{1,3}$ and Yafeng Lu ${ }^{1,3}$
}

1 Institute of Mountain Hazards and Environment, Chinese Academy of Sciences, Chengdu 610041, China; xupei@imde.ac.cn (P.X.); fubin@imde.ac.cn (B.F.); yankun@imde.ac.cn (K.Y.); liuqin@imde.ac.cn (Q.L.); luyafeng@imde.ac.cn (Y.L.)

2 University of Chinese Academy of Sciences (UCAS), Beijing 100049, China

3 Wanzhou Key Regional Ecology and Environment Monitoring Station of Three Gorges Project Ecological Environmental Monitoring System, Wanzhou 404020, China

4 National Society for Earthquake Technology-Nepal, Kathmandu Lalitpur, Po. Box 13667, Nepal; adixit@nset.org.np

5 Central Department of Geography, Tribhuvan University, University Campus, Kirtipur, Po. Box 44613 Nepal; nrkhanal.geog@gmail.com

* Correspondence: wangyukuan@imde.ac.cn (Y.W.); suresh.nset@gmail.com (S.C.); Tel.: +86-028-8523-0627 (Y.W.)

Received: 9 June 2018; Accepted: 29 June 2018; Published: 5 July 2018

\begin{abstract}
The abandonment of farmland is a phenomenon that shows the deterioration of the physical and social landscape. It is widespread across the mountainous region of Nepal and is expected to further increase in the future. The aim of this study is to: (i) determine the driving factors of farmland abandonment; (ii) discuss its impact on social systems in terms of social networks, relations, practices; and (iii) assess the eco-environmental vulnerability of abandoned farmlands in the high mountain region of Nepal. The authors apply household surveys, focus group discussions and in-depth key informant interviews to visualize the social landscape and changes therein, thus establishing an existing history of mountain societies, social systems and management practices. Moreover, Google Earth Images and Low Height Remote Sensing Survey (UAV) are also used to observe geomorphic processes and the modification of the abandoned farmland and its characteristics. The Multivariate Linear Regression (MLR) model is run using SPSS revealing eight variables; mountain road accessibility, farm distance from residence, household size, household head age, landowner's living place, ownership of farmland, salary and business and remittances are major factors determining the process of farmland abandonment in the region. Farmers' social practices such as (i) an indigenous labor exchange system "Parma," (ii) a traditionally managed irrigation system, (iii) a drinking water supply system, (iv) social practices, rituals, festive events, (v) an indigenous governance system, practices and some existing infrastructures (schools, banks, health, post, temples and more) are going to disappear as a process of abandonment. The decline in individual as well as social participation in land management practices have increased exotic vegetation and soil loss processes, modifying the physical characteristics of abandoned farmlands. Thus, this knowledge is vital for understanding appropriate social processes, natural resources and environmental management.
\end{abstract}

Keywords: farmland abandonment; social practices; farmland degradation; mountain region; Nepal 


\section{Introduction}

Recently, farmland abandonment has been a major phenomenon regarding the deterioration of the physical and social landscape, especially in the mountainous regions of Nepal [1-4]. Globally, it is estimated that about 385-472 million hectares is abandoned farmland, accounting for 8-10\% of total cultivated land [5]. The processes of urbanization, population migration and other socio-economic factors indicate that there will be increases in the amount of abandoned farmland [1]. Primarily, farmland abandonment accompanies a decline in cropland area but, wherever farmland abandonment occurs, the social, cultural and physical environments are also undergoing structural changes in mountain societies and ecosystem service provisions $[3,6,7]$. The abandonment process and occurrence of farmland abandonment are uncertain but can aggravate the vulnerability of the mountain landscape, as well as lead to the breakdown of traditionally developed socio-cultural and farming systems [1,8,9].

The abandonment of farmland adds a new dimension to the mountain environment and society [10-12]. Specifically, plant succession and soil loss processes [13], changes in biodiversity [14], carbon sequestration [15], eco-hydrology [16] and mountain ecosystem service provisions [6] are often considered global issues. Additionally, the issues of land use intensities and the shaping of the mountain services $[17,18]$, climate change by the transformation of mountain farmland use and landscape [19], land use change impacts on vegetation and biodiversity [20], spatial arrangement of bio-physical and socio-economic factors and their role in mountain landscape change [9], pressures of social, economic and technological development damages to mountain ecological and environmental balance [21] are mostly discussed in the existing literature. However, literature on farmland abandonment consequences regarding societal preferences is very scanty. Specifically, knowledge about farmland abandonment, changing perceptions of the social landscape, impact on the social system and its implications for managing the eco-environmental vulnerability of farmlands is still poor.

The mountain region of Nepal is highly varied in terms of topography, climate and biodiversity. The region has also a very high level of social diversity. It covers $83 \%$ of the country's land area and is home to more than 100 social groups consisting of approximately 50\% of the total population [22,23]. The large proportion of the mountain population generates a farmland environment offering a unique landscape of agricultural terraces [24]. Throughout the region, social systems integrate all the social groups within the community forming vital networks among households [25]. Villagers occasionally work together to implement village level projects, such as building irrigation canals, facilities for drinking water, local treks, schools, temples and other households. The farm households usually rely on a mutual labor sharing system called "Parma" to perform farm activities during the peak hours, which allows villagers to exchange labor in times of need [26]. However, the agricultural systems including natural resource use and management have been changing and many of the farmlands are reported to be abandoned [27-29].

An acceleration of farmland abandonment is a new phenomenon in Nepal. Manandhar (2014) expressed that the 10-year long conflict between the Nepal government and Maoist Insurgency (during the period of 1996-2006) corresponds with the first land-use transitions and the evolution of farmland abandonment throughout the country [25]. During this period, the Nepal government continued its struggles in the capital cities; public services and resources became centralized and mountain societies increasingly began to express their own stake (social relations, labor availability and the use of agricultural resources) in the abandonment process [30,31]. The most notable change is the growing sense of insecurity that is pushing the farmers to abandon distant farmland and focus mostly on nearby home farmlands. The second farmland transitions began in 2006-2007 and onward. Basically, after the movement, a substantial rate of population migration from rural to urban centers and/or rural to outside countries occurred [22]. The conditions became beyond the affordability/availability of farm labor for an individual household. As farmlands were abandoned, household farming tools and livestock were given up as well. However, some farmers who began organizing themselves into groups to pool their personal resources for common benefit are still undertaking farm activities in the mountain region. 
The aim of this study is to; (i) determine the driving factors of farmland abandonment; (ii) discuss the impact on social systems in terms of social networks, relations, practices; and (iii) assess the eco-environmental vulnerability of abandoned farmlands in the high mountain region of Nepal.

\section{Materials and Methods}

\subsection{Study Area}

This study was carried out in the Dordi river basin, which is located $\left(28^{\circ} 8^{\prime} \mathrm{N}-28^{\circ} 27^{\prime} \mathrm{N}\right.$, $84^{\circ} 24^{\prime} \mathrm{E}-84^{\circ} 42^{\prime} \mathrm{E}$ ) in the western mountain region of Nepal (Figure 1). The basin is characterized by a subtropical climate zone with an annual average temperature between 10 and $29{ }^{\circ} \mathrm{C}$ and annual precipitation of $2602 \mathrm{~mm}$. It covers an area of 498 square kilometers involving 10 village development committees; Faleni, Dhodeni, Bansar, Hiletaksar, Pachok, Nauthar, Chiti, Shree Bhanjyang, Gauda and Archalbot. Forest is the dominant land use, accommodating $42 \%$ of the area, followed by farmland and grassland $21 \%$ and $11 \%$ respectively. Soils are predominantly red, yellow and hydromorphic paddies [32]. The main vegetation type includes sal (Shorea robusta), Schima, Castanopsis and Engelhardtia forest [32]. The area mainly comprises two types of farmlands; Khet and Baari. Khet are generally used to grow rice and wheat, whereas Baari is used to plant rain-fed crops; maize, millet, oilseeds and pulses. Khets are normally bordered to stop surface runoff. However, the size of both types of farmland is very small, on average, compared to those in plain Terai areas [22].

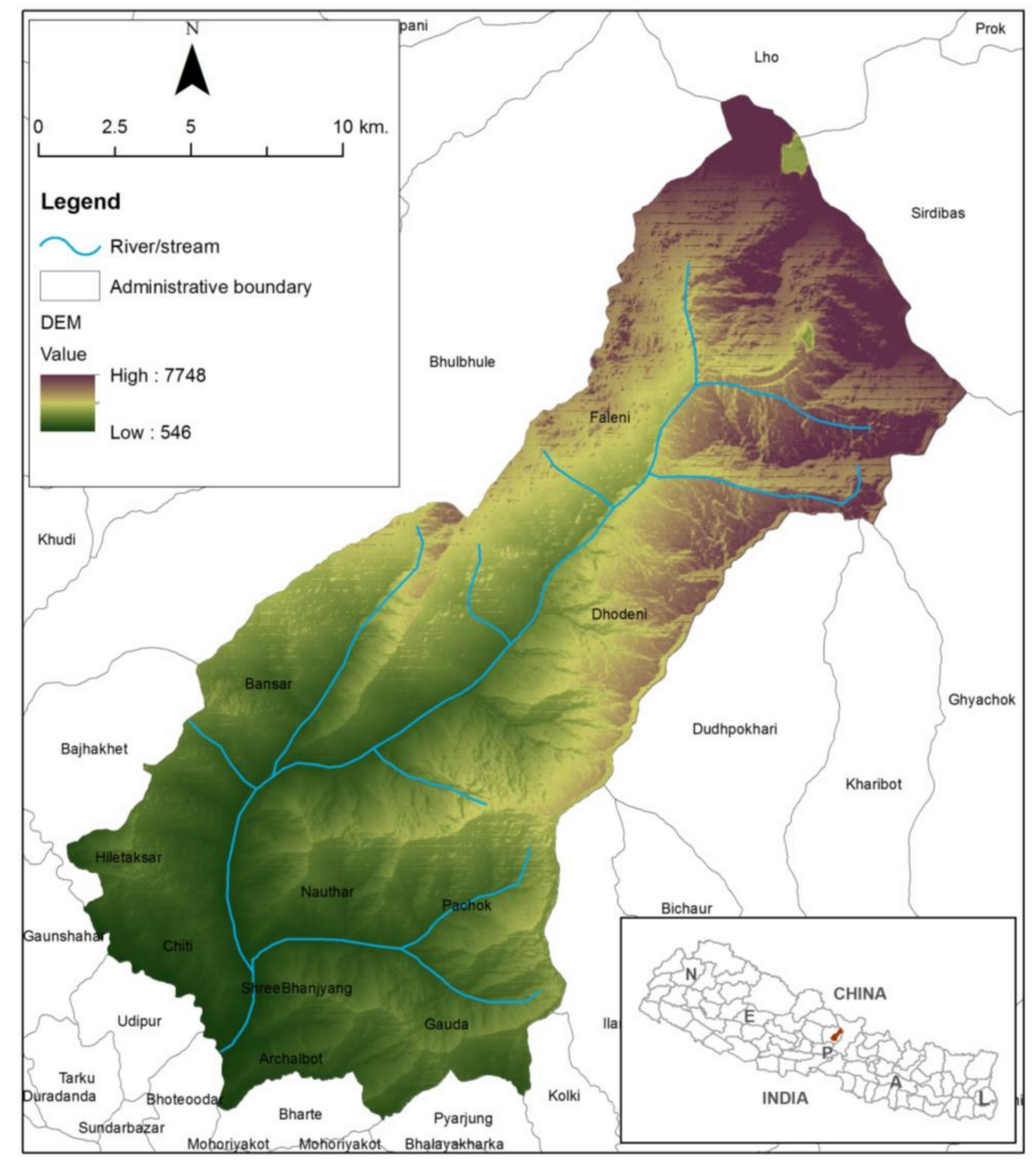

Figure 1. Location Map of Study Area. 
The basin is also gifted with the beauty of nature as well as being rich in folk cultures of various castes and ethnic groups [22]. Particularly, the spatial distribution of settlements and their morphological expressions, such as adaptation to varying altitudes, slopes and aspects has endowed high social, ecological and environmental significance. Agriculture, salaried jobs, labor migration and wage labor are the major sources of household income [33]. Migration to seek more off-farm activities or labor migration have caused a rapid decrease in the population over the years [25]. The farmlands, which were representative of the traditional socio-ecological unit of the landscape, have been abandoned in significant numbers [27]. Additionally, the process of soil erosion and landslides are intensifying on cultivated as well as abandoned farmlands [34]. Even though a series of agricultural development plans and activities have been implemented in the region, these problems still exist. However, distinct bio-physical, socio-economic and a lack of physical infrastructure throughout the basin create varying levels of opportunities and constraints for hydro-potentiality and tourism-related business activities. The basin, with distinct topographic and socio-economic characteristics, was selected for this study to capture the many driving factors for abandonment and the resultant changing social systems that prevail in the western region of Nepal.

\subsection{Household Data and Sampling}

A well-structured household questionnaire was used to obtain information about household socio-economic information, land-use characteristics, status of abandoned farmland, perceptions regarding soil fertility, approximate distance of farm and forest from residential houses, accessibility to road and market, as well as soil and water management techniques and more. Since household survey forms were too time consuming (per household 2:30 h), each household respondent was asked about their available time. Following commitment to do the survey, the authors began collecting household information. The survey was piloted from July to September in 2017. The sample size was composed of 154 households. The selection of the surveyed household was determined according to stratified random sampling. Proportional distribution of all social groups residing in this area was considered during the household survey including newly migrated households, such as family members from Chepang communities, were considered as one household.

Aside from the survey, socio-economic data at the country level were derived from the National Statistical Book of 2011, published by Central Bureau of Statistics [22] and Human Development Report published by UNDP [35]. IBM SPSS Statistics software, Version 23 (IBM in Armonk, NY, USA) and Microsoft Excel (Microsoft Office Enterprises 2007) were used to record quantitatively collected households' socio-economic information.

\subsection{Focus Group Discussion (FGD) and Key Informants Interview (KII)}

Following the household survey, various formal and informal key informants interview (KII) and focus group discussions (FGD) were also conducted to gain in-depth information and elicit subjective experiences on social systems, changing farm activities, perception of the social landscape, socio-cultural activities, social festivals, traditional institutions, the community's irrigation and drinking water management as well as status and problems initiated due to abandonment.

Open-ended questions were designed in a tabular form and used for both key informant interviews and focus group discussion activities. Prior to conducting an interview and the focus group discussions, all participants and respondents were briefed about the type of questions, the main purpose of the research and the discussion procedures. A total of 8 focus group discussions, comprising 8-10 members each and 40 key informant interviews were conducted. The participants of both activities were mainly older people, local political leaders, teachers, social mobilisers, farmers and owners of abandoned lands. The group discussions were conducted during the morning at nearby tea shops or school grounds. Interviews, however, were done according to the availability of the respondent's time and location. Both were conducted in the Nepali language. 


\subsection{Selection of Farmland Abandonment Driving Factors and Multivariate Regression Analysis}

Farmland abandonment is a complex process which involves the natural mountain landscape, socio-cultural development and national land use policies. The process starts with farmers perceiving agricultural activities as a difficult task, which is influenced by the three factors mentioned earlier. The decision to choose land abandonment or management depends on a farmer's perception as well as the household characteristics, land characteristics, institutional support provided and the environmental/location characteristics of the farmland. Previous research has considered farmland size and low-level production accompanied by permanent natural handicaps like topography, soil, climate and altitude [13,36-38] as major factors. The commercialization of agriculture or low innovative farming systems $[3,13]$, land tenure systems, social security, the farmer's age, lack of urban facilities [3,39], difficulties in land management [40], low level of available household labor [1,4], the breakdown of social conditions [39] and governmental rule and policies for land use [41] also instigate land abandonment. Additionally, land management systems such as terracing, surface runoff, soil degradation, landslides, frequent flooding, overexploitation and productivity losses have been regarded as driving factors [40]. Furthermore, those who are literate and have relatively better exposure to society and opportunities for non-farm activities [42] tend to leave the area. However, some of the driving factors would not be appropriate in the case of Nepal. Thus, a key issue is specifying which factors are most relevant in the context of the mountain region of Nepal.

The authors applied Multivariate Linear Regression (MLR) analysis to determine what factors are acting significantly during the process of farmland abandonment in the mountain region of Nepal. It was assumed that farmland abandonment is a function of several variables including environmental/locational characteristics, land characteristics, household characteristics, physical capital and income sources. Therefore, understanding the mountain context of Nepal and reviewing the relevant literature, a total of 18 asset-based explanatory variables were selected for this study. The selected variables, their definitions and expected relationships to farmland abandonment are summarized in Table 1. All analyses were carried out using IBM SPSS Statistics software, Version 23 (IBM in Armonk, NY, USA)

Table 1. Selected variables, their definitions and expected relationships to farmland abandonment.

\begin{tabular}{|c|c|c|}
\hline Explanatory Variables & Definition & Expected Relationship to Farmland Abandonment (FA) \\
\hline \multicolumn{3}{|l|}{ A. Environmental/Locational } \\
\hline Elevation & $\begin{array}{l}\text { Elevation of each household recorded } \\
\text { by GPS }\end{array}$ & $\begin{array}{c}\text { Households located at higher elevations are more likely to } \\
\text { have a higher number of abandoned farmlands }\end{array}$ \\
\hline Market access & $\begin{array}{l}\text { Nearest market center for household } \\
\text { use }(\mathrm{km} .)\end{array}$ & $\begin{array}{l}\text { Households located near to market centers are expected to } \\
\text { adopt commercial farming }\end{array}$ \\
\hline Accessibility of road & Distance to vehicle passable road (meter) & $\begin{array}{l}\text { Households located closer to roads are more likely to } \\
\text { adopt commercial farming }\end{array}$ \\
\hline \multicolumn{3}{|l|}{ B. Land Characteristics } \\
\hline Farm distance from residence & Minutes travel to farmlands & $\begin{array}{l}\text { Farmlands far from residential houses are more likely to } \\
\text { be abandoned }\end{array}$ \\
\hline Productivity & Annual production $(\mathrm{kg})$ & $\begin{array}{c}\text { Farmlands with less productivity are more likely } \\
\text { for abandonment }\end{array}$ \\
\hline Irrigation Access & $\begin{array}{l}\text { An availability of farmer managed } \\
\text { irrigation canal }(\text { Yes }=1, \text { No }=0)\end{array}$ & $\begin{array}{l}\text { Farmlands having no irrigation facilities have a higher } \\
\text { likelihood for abandonment }\end{array}$ \\
\hline \multicolumn{3}{|l|}{ C. Household Characteristics } \\
\hline Household size & Total household members & $\begin{array}{l}\text { Households with a bigger family sizes are expected to } \\
\text { continue farm activities }\end{array}$ \\
\hline Household head age & Age of household head (years) & $\begin{array}{l}\text { Households with an older head are more likely to } \\
\text { abandon farmland }\end{array}$ \\
\hline Household head Schooling year & Schooling year of household head & $\begin{array}{l}\text { Households head with a higher education are more likely } \\
\text { to abandon farmland }\end{array}$ \\
\hline Living places & $\begin{array}{l}\text { Land owner living (same villages }=1, \\
\text { other areas }=0 \text { ) }\end{array}$ & $\begin{array}{l}\text { Farm owners living in the same villages are more likely to } \\
\text { continue farm activities }\end{array}$ \\
\hline Access to credit & Yes $=1$, No $=0$ & $\begin{array}{l}\text { Households having access to credit are more likely to start } \\
\text { up a new enterprise while abandoning their land }\end{array}$ \\
\hline
\end{tabular}


Table 1. Cont.

\begin{tabular}{|c|c|c|}
\hline Explanatory Variables & Definition & Expected Relationship to Farmland Abandonment (FA) \\
\hline \multicolumn{3}{|l|}{ D. Physical Capital } \\
\hline Ownership of Farmland & $\begin{array}{l}\text { Total Farmland owned by } \\
\text { Households (Ropani) }\end{array}$ & $\begin{array}{l}\text { Households owing large number of farmlands are more } \\
\text { likely to abandonment }\end{array}$ \\
\hline Livestock Value & Livestock monetary value (NPR). & $\begin{array}{c}\text { Households owning many livestock are less likely to } \\
\text { farmland abandonment }\end{array}$ \\
\hline \multicolumn{3}{|l|}{ E. Income Sources } \\
\hline Farm Income & Annual income (Nepalese rupees) & $\begin{array}{c}\text { Households having higher crop income are less likely to be } \\
\text { abandoned }\end{array}$ \\
\hline Livestock Income & $\begin{array}{l}\text { Annual income } \\
\text { (Nepalese rupees) }\end{array}$ & $\begin{array}{l}\text { Households with more income from livestock are less } \\
\text { likely to be abandoned }\end{array}$ \\
\hline $\begin{array}{l}\text { Remittances (labor out migration, } \\
\text { pension and seasonal migration) }\end{array}$ & $\begin{array}{l}\text { Annual income } \\
\text { (Nepalese rupees) }\end{array}$ & $\begin{array}{l}\text { Households with sufficient remittances more likely } \\
\text { to abandonment }\end{array}$ \\
\hline Salary and business & $\begin{array}{l}\text { Annual income } \\
\text { (Nepalese rupees) }\end{array}$ & $\begin{array}{l}\text { Households members with salary/pension are expected } \\
\text { have less abandonment }\end{array}$ \\
\hline $\begin{array}{l}\text { Wage labor (agricultural and } \\
\text { non-agriculture) }\end{array}$ & $\begin{array}{l}\text { Annual income } \\
\text { (Nepalese rupees) }\end{array}$ & $\begin{array}{c}\text { Households having good quality of house are expected } \\
\text { have less farmland abandonment }\end{array}$ \\
\hline
\end{tabular}

\subsection{Delineation and Characterization of Abandoned Farmland}

Primarily, a large piece of recently downloaded Google images (for 2017, printed on A1 paper sizes) were used for identifying abandoned farmlands in the study area. Initially, members of ward offices, elected presidents, teachers, social mobilisers and villagers were asked to mark on the Google images printout, showing where the total area of abandoned farmland was and when it occurred. Throughout the process, a lot of abandoned farmland was identified and categorized according to the time of abandonment; $<1$ years, $1-2$ years, $2-5$ years, $5-10$ years and $>10$ years. Then, a team of researchers directly visited the different categories, altogether 38 abandoned farmlands and observed the changes to the geomorphic process (terrace damage, gully formation, small landslides and more) and vegetation succession. Moreover, an Unmanned Aerial Vehicle (UAV)-DJI Phantom 4 Pro plus Quadcopter with Deluxe Controller-CP.PT.000549 was used to capture low-height remote sensing imagery of certain abandoned farmlands. More than 4000 images (at a dimension of $4000 \times 3000$ pixels for each image) were collected and combined using Agisoft Photo Scan Professional-64 bit (Agisoft LLC 11 Degtyariy Per., St. Petersburg, Russia) and eCognition Developer 64 software (Arnulfstrasse 126, Munich, Germany). The holistic view, based on the UAV images, allow an object-based evaluation and direct observation of the structural changes in the physical landscape, where big changes in spatial patterns are easily detected and visually interpreted (Figure 2).
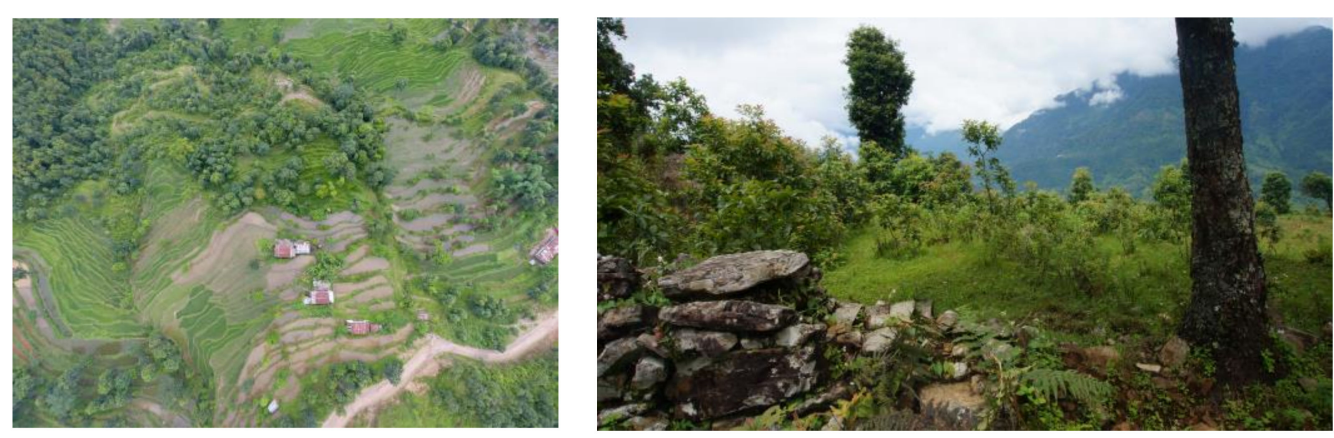

Figure 2. UAV Captured Images and Plant Succession on Abandoned Land.

Vegetation succession patterns and type of plant species were also documented over the 38 observed abandoned farmlands. Regarding each tree, species, height, diameter at breast height $(\mathrm{DBH}=$ approximately $1.3 \mathrm{~m}$ above ground $)$ and density coverage over the plot were recorded $(10 \mathrm{~cm}$ $>\mathrm{DBH})$ as well as shrub species number and percentage of coverage $(10 \mathrm{~cm}<\mathrm{DBH})$. Density coverage was also determined through visual observation and recorded according to $<1 \%, 2 \%, 5 \%, 15 \%, 25 \%$, $50 \%, 75 \%$ and $100 \%$. The numbers of shrub and tree species recorded in this study for each abandoned farmland were considered "mean dominant richness," as the sampling of plant species was not 
comprehensive. Local people were consulted to gather information such as time since abandonment, causes of abandonment, historical land use, vegetation succession and physical landscape changes over the years.

\section{Results and Discussion}

\subsection{Determining Driving Factors of Farmland Abandonment}

Multivariate Linear Regression (MLR) analysis was applied to determine the major driving factors prompting the abandonment process of mountain farmlands in Nepal. The results of the multivariate regression are presented in Table 2 . The results revealed that farmland abandonment is positively and significantly influenced by the seven independent variables: availability of road accessibility $(\beta=0.010$, $p=0.004)$; Farm distance from residence $(\beta=0.127, p=0.039)$; Household head age $(\beta=0.056, p=0.013)$; Landowner currently living places $(\beta=1.457, p=0.033)$; ownership of farmland $(\beta=0.095, p=0.002)$; Salary and business $\left(\beta=2.777 \times 10^{-6}, p=0.007\right)$; and Remittances $\left(\beta=5.650 \times 10^{-6}, p=0.016\right)$. Conversely, there were significant but negative influences of household size $(\beta=-0.361, p=0.041)$ while the remaining ten variables such as mountain elevation, market access, farmland productivity, irrigation access and education of household head, access to credit, farm income, livestock income and wage labor activities, did not have significant relationships, although the direction of their relationship to farmland abandonment bears important policy implications in the mountain region.

This study identified eight distinct factors-mountain road accessibility, farm distance from residence, household size, household head age, landowners living places, ownership of farmland, salaried jobs and business and remittances-affecting the process of farmland abandonment in the mountain region of Nepal. However, the roles of these driving factors are not equally distributed. Household characteristics such as; farmer's household size, household head's age and landowners living places significantly influence the cultivation of farmland. The leading roles of economic agriculture and forming the mountain social landscape are diminishing factors, as farmers, who formed the majority in the past, are becoming a minority. This study also revealed that mountain society and the lifestyle of farmers has been changed substantially in recent decades. The most significant changes have been; (i) the abandoning of farmland and their own society and migrating to urban areas; (ii) the decline in farm and livestock ownership and involvement in off-farm activities; a salaried job or business. As illustrated in the focus group discussion, participants felt that "farming took a long time to get something from field" so their income was not steady whereas joining in other sectors such as salaried jobs or in business allowed them to earn a monthly income. Thus, every household is trying to change their profession".

The results demonstrate a positive and significant relationship regarding the household head's age. As indicated by the above results, more than $80 \%$ of households were found to have only aged people at home. These results seem reasonable because growing migration to cities and abroad have a marked aging effect on the household populations in Nepal [22]; as active household members migrated, elderly people became responsible for farmland management and community social activities. Additionally, in Nepal, household heads are the only ones who make the decisions in the management of farm activities or the abandonment of farmland [43]. Household heads who were under 40 found strong and logical capacity in the adoption of new technologies for farming, seeding and plantation. They were more aware of seeds and production information and got necessary support from the government and non-government organizations. To contrast, illiterate and older farmers were not looking for such opportunities, which inhibited them from continuing farming activities. Furthermore, they did not accept any kind of training related to farm and farming activities. Their cropping patterns were whatever neighboring farmers did on their farm. Furthermore, farm activities over the basin were highly labor intensive. Farmers have to plough land two or three times, maintain terraces yearly, cultivate crops and take out weeds and harvest crops. Farm machinery such as tractors cannot be used due to steep slopes and small terraces [44]. Household heads are the major 
source of labor for farming activities. When farmers want to improve farmland, active laborers were required in substantial numbers for constructing terraces, dams and retention walls, which is beyond the affordability of the older farm owner.

Table 2. Determinants of driving factors for farmland abandonment over the basin.

\begin{tabular}{|c|c|c|c|}
\hline Explanatory Variables & B-Coefficient & Standard Error & Significance \\
\hline \multicolumn{4}{|l|}{ A. Environmental/Locational Characteristics } \\
\hline Elevation (meter) & -0.001 & 0.0009 & 0.188 \\
\hline Market access (km.) & -0.088 & 0.2051 & 0.668 \\
\hline Road accessibility & 0.010 & 0.0034 & $0.004 * *$ \\
\hline \multicolumn{4}{|l|}{ B. Land characteristics } \\
\hline Farm distance from residence (required time) & 0.127 & 0.0614 & $0.039 * *$ \\
\hline Productivity (kg) & 0.000 & 0.0003 & 0.125 \\
\hline Irrigation access & 1.455 & 1.9443 & 0.454 \\
\hline \multicolumn{4}{|l|}{ C. Household characteristics } \\
\hline Household size & -0.361 & 0.1764 & $0.041^{* *}$ \\
\hline Household head age & 0.056 & 0.0227 & $0.013 * *$ \\
\hline Household head schooling year & 0.070 & 0.0799 & 0.380 \\
\hline Household head living places & 1.457 & 0.6824 & $0.033^{* *}$ \\
\hline Access to credit & -1.538 & 1.1619 & 0.186 \\
\hline \multicolumn{4}{|l|}{ D. Physical capital } \\
\hline Ownership of farmland (Ropani) & 0.095 & 0.0312 & $0.002 * *$ \\
\hline Livestock value (NPR) & $4.131 \times 10^{-6}$ & $2.681 \times 10^{-6}$ & 0.123 \\
\hline \multicolumn{4}{|l|}{ E. Income sources } \\
\hline Farm income & $1.585 \times 10^{-5}$ & $3.822 \times 10^{-5}$ & 0.678 \\
\hline Livestock income & $1.576 \times 10^{-7}$ & $4.472 \times 10^{-6}$ & 0.972 \\
\hline Wage labor & $1.766 \times 10^{-6}$ & $2.971 \times 10^{-6}$ & 0.552 \\
\hline Salary/Business & $2.777 \times 10^{-6}$ & $1.021 \times 10^{-6}$ & $0.007^{* *}$ \\
\hline Remittances (labor migration, pension, seasonal migration) & $5.650 \times 10^{-6}$ & $2.334 \times 10^{-6}$ & $0.016^{* *}$ \\
\hline
\end{tabular}

Log Likelihood = -369.378; Pearson Chi Square = 1241.609; Omnibus Test-Likelihood Ratio Chi Square = 145.625; $\mathrm{P}=0.000$ Akaike's Information Criterion $(\mathrm{AIC})=778.756$; Bayesian Information Criterion $(\mathrm{BIC})=838.835$; Significant at $* * 95 \%$. Depended variable $=$ abandoned land (Ropani); Model: (Intercept), Elevation $(\mathrm{mt})$, Market access $(\mathrm{km})$, Road access $(\mathrm{mt})$, Farm distance (min), Irrigation productivity $(\mathrm{kg})$, Household size, Household head age, Household head schooling, Household head living places, Access to credit, Total farmland (Ropani), Livestock value (NPR), Farm income (NPR), Livestock income (NPR), Wage labor income (NPR), Salary/Business income (NPR), Remittances (NPR).

Remittances were another important factor affecting farmland abandonment in the mountain region of Nepal. Regular cash flow from remittances and pensions (from retirement) have been a traditional and important feature of rural existence [45]. The majority of household incomes were collected from remittances and spent on daily basic needs such as education, health, food and more [46]. The increasing role of remittances including labor migration, pension, seasonal migration and so on in Nepalese households and the national economy of Nepal is widely discussed in the empirical research and national reports [4,22,47]. During this study's household survey, many respondents proudly expressed that "remittances have enabled family members to move to urban areas for a child's schooling at private schools. It has also improved the living conditions of mountain communities. Old parents were convinced to care for the parental home without involving any farm-activities. Additionally, elderly parents at rural homes were enjoying modern facilities such as television with a cable network, refrigerator, cooling fans and more. Remittances additionally allowed mountain farmers to consume urban food like noodles, biscuits and cold drinks and so on despite fresh produce and the availability of traditional foods such as popcorn, soybeans and local drinks (Wine and Jaand)."

Land ownership status also indicated a positive and significant relationship in the abandoning of farmland. It is the reality that the amount of farmland determined the household social status, access to credit and political participation in Nepal [48]. The greater the quantity of land owned means the better ability to benefit from public services such as education and health. However, an undeveloped status 
of agriculture, a lack of irrigation, the use of traditional technology and the subsistence production of farmlands have rendered even relatively large landholders into the state of abandonment [27]. Furthermore, the people who possess small parcels of land that provide very little income are less interested in agriculture. These people, therefore, do not pay much attention to farming or land management. Thus, if the land productivity was high and labor was available to farmers, lands were farmed on a share-cropping basis and a fixed proportion of land production was shared with the landowner. However, in that case, farmers were not adopting new practices and modern seeds because they thought that most of the benefits went to the landowner.

The farm distance from the farmer's residence also shows a closer relationship to abandoning the mountain farmland. Farm cultivation and management required regular attention [28] so farmlands far from the residential house cannot be properly maintained. Additionally, there are not any defined grazing fields in Nepal [49]. Existing farmlands (during the off-season), abandoned farmlands as well as nearby forest areas are normally used for grazing. A large area of abandoned farmland has allowed for the propagation of shrubs and other unplanted species resulting in the degradation of pastures. Following the conversion of farmland into forest, many kinds of wild animals such as rabbits, rats and monkeys are heavily increased around the nearby farmland areas [50]. Farmers use traditional measures to prevent these animals such as using an elastic weapon/ (slingshot) and regular monitoring of the croplands, however, these measures are not effective for the larger farmlands or farmlands more distant. This study's FGDs found many farmers expressed that their farmland use was disturbed by grazing activities, forest animals and invasion of alien species on neighboring abandoned farmland. Farmers believed that cropping at only one farm attracted many wild animals at once.

\subsection{Impact on Social System}

Social landscapes are important in the mountain regions, particularly for farming activities as well as natural resource management [51]. It is well established in the traditional mountain landscapes, which formed due to a generic organizational pattern of private and common agricultural land units distributed along the altitudinal variations [52]. The units also have a distinct and recognizable structure for providing institutional support in terms of natural environment (soil, vegetation), social environment (institutional organizations, irrigation and/or water supply management), farmland planning (terraces), farmland activities, employment opportunities and socio-cultural functions [53] and, in turn, farmers are delivered farm and other natural resource based products. The authors have presented how abandoning farmland has an increasing impact on labor exchange system, social systems, practices, networks and relationships in Nepal.

\subsubsection{Indigenous Labor Exchange System "Parma"}

"Parma" is one of the most prevailing, interactive and dynamic social systems for giving and receiving help for labor services in turn collectively [26,54]. The system simply refers to interchanging help at the time of planting or harvesting crops, building shelters, roofing houses and more. People in the mountain community lend "Parma" labor to each other to complete the household work. The systems are pooled together to implement village-level projects, such as building irrigation ditches or channels, or facilities for drinking water. The system enables people to live even in harsh conditions (during natural disasters) without any modern infrastructures and facilities [26]. Thus, it developed a rich stock of social institutions among mountain communities.

Since the establishment of mountain communities, Parma was practiced among farmers. The increasing abandonment of farmland has seen the practices of "Parma" being less or not practiced among societies. Regarding the focus group discussions (FGD), participants strongly mentioned that there were no longer household members to participate in "Parma" activities. Additionally, there were no farmland activities requiring the "Parma" system. The practice of "Parma" have begun disappearing in most of the communities. Although the system was like a social trust established to help each other or to support agricultural functions in time of need, it was mostly found among the 
people of the same social groups or communities settled at one location. Thus, this type of practice, on one hand, brought the social community closer and on the other hand made it easier to perform agricultural functions. Therefore, since the practice of "Parma" activities have dissipated, the value of traditional systems will be hindered and it will lead toward social landscape fragmentation in the future.

\subsubsection{Irrigation Management System}

The irrigation management system is another means for the mountain farmers to organize themselves and is invested heavily in the construction and maintenance of their own irrigation canal. The system is also one of the many traditional systems that has existed in the mountain region for several centuries $[55,56]$. According to the irrigation management system, irrigation dams at the source and many smaller feeder canals are built of earth, rocks and wooden blocks and passed along the edge of farmland terraces. The source and smaller feeder canals are rebuilt or simply maintained and cleaned from scratch at the end of each monsoon, normally in the months of May-June and October-November, before the plantation of rice and wheat respectively. However, the making of bunds, constructing headworks, building irrigation canals and ditches, setting and adjusting field canals did not happen suddenly. Groups of farmers conceptualized their ideas and decided what to do first and who should do what; they argued, had conflict and settled disputes, built and rebuilt, coped with floods, landslides and droughts and, in the process, created social rules and regulations.

Water was allocated through a rotational system whereby fields were irrigated on a turn by turn basis. Initially, it was allocated to the land nearest to the source. Once the fields were fully irrigated, the gates were closed and the outlets to the next farmland were opened. These processes were continued until all fields along the command area received water and then the process began again. Each household member was concerned about the water availability and status of irrigation canal. All household members voluntarily were involved in the repairing of canals. Normally, each household was expected to provide one family member as a laborer for one day and while the expected labor contribution was higher, it was, regardless of how many farmers or population existed there. However, the decreasing numbers for labor participation and the increasing difficulties for the management of the irrigation system in the recent years through the abandonment of farmlands in the command area, found many feeder canals damaged. Local farmers expressed that some of the irrigation canals were blocked due to abandoned farmlands inducing sedimentation, terrace damage and mudflows. They also stated that the indigenous irrigation systems have been unsustainable in the context of skewed farming activities and/or the increasing abandonment of farmlands.

\subsubsection{Drinking Water Management}

Natural springs are the major source for drinking water supplies throughout the basin. Usually, delineation of water resources, techniques for harvesting and management of water supplies were traditionally organized by the farmers themselves. Building stone and concrete walls, fencing boundaries with wire, planting trees and restricting access of people and animals are the farming community's efforts toward conserving drinking water resources. The supplies of water are settled according to the local environment and living conditions of the societies [57]. Additionally, local people share religious beliefs to protect the natural springs. According to beliefs, the place where a natural spring originates was the place of the Snake Goddess. They believe that polluting the habitat of the Goddess or cutting of bushes and trees around the springs causes natural calamities such as drought, landslides and more. Recently, the water from the springs is pumped and stored in cemented water tanks in a nearby village, however harvesting and supply management are still community based to a large extent.

Well-maintained terraced farmland can act as a reservoir detaining water for spring sources [58]. Many spring water sources are vanishing or drying up due to people leaving ancestral settlements as well abandoning terraced farmland leaving no one to maintain the systems. Some of the water 
resources that a household had been using for many years have been completely dried. Additionally, many water sources have less discharge, making it difficult to have supplies for drinking, livestock and irrigation purposes. Soil sedimentation and the occurrence of landslides and so on are also noticeably due to farmland abandonment leading to severely affected water sources throughout the basin. Participants in the FGDs expressed that increasing farmland abandonment, thus lack of human resources and regular maintenance of natural springs, are snowballing the drinking water shortages in the region. They also claim that household workloads are increased due to more time required for washing clothes, maintaining general cleanliness, and/or drinking water forage. Some households resort to collecting water during the night while others are obliged to collect unclean water, inviting water-borne diseases. Thus, it is urgent to identify strategies for improving drinking water sources to prevent human and environmental disasters in the mountain region.

\subsubsection{Social Practice, Rituals and Festive Events}

There are a lot of social practices, traditions, cultures and festive events (Birth, Marriage, Death, Bratabandh, Shraddha, Annual puja, Jatra, Naach and so on), requiring day-to-day neighborhood relationships $[59,60]$. The Hindu religion requires one member of each village called "Puret" or "or "or "Dhami" or "Lama", to be assigned to perform these social ritual practices and festive events. Literally, these members are a "ritual leader," but traditionally they were used to specify an informal cultural institution, referring to the social landscape dated from the establishment of village. Under this person, villagers perform religious activities, organize social and agriculture-related festivities, bring reforms in traditions and customs, strengthen social and production systems, manage resources, settle cases and discussed activities for recreation and social solidarity. The practices are varied from small gatherings to large-scale social celebrations and commemorations. Particularly, these practices are referred to a person or a group of persons who want to be involved. Festive events are a key part of public life and often opened to all members of society. These events often take place at special times and remind farmers about the community's place in the worldview and its perception of its own history and memory.

These social practices are important for shaping everyday community life while making it familiar to all members of the community. Most importantly, these help to mark the passing of seasons, historical events in the agricultural calendar or the stages of a person's life. Additionally, the practices are significant to reaffirm the identity of those who practice them as a group or a society. However, these kinds of functions are now socially doomed. Communities indicate that, since many farmers are moving out and abandoning their farmland, it is hard to find ritual leaders and gather the population in the villages. There currently are no ritualistic and festive events of any kind, even once.

\subsubsection{Indigenous Governance Systems, Practices and Other Infrastructures}

The practices of indigenous governance systems-Kulharis and Mukhiyas-evolved over long periods of time in the mountain region. Kulharis and Mukhiyas are people who play a central role in facilitating actions and/or increase access, use of resources and assets. Especially under the Kulharis system, whole farming communities are divided based on farm sizes and allocated water resources either one full day or a limited few hours to irrigate their fields as a result. The governance systems are locally adopted, environmentally sound and suited to the specific mountainous biophysical conditions [61]. The governance system and practices are renowned for the art of using farmland, maintaining soil fertility as well as water and forest resource management, which has been passed from generation to generation. Additionally, they work to preserve the cultural and natural environment, which are directly linked to the community's socio-economic life.

Under the governance system, mountain people have a strong sense of community stewardship, since the whole community takes responsibility for protecting, maintaining or managing properties such as farmland, irrigation canals, forest and grasslands. Keeping animals in an open farmland, migratory flocks of sheep or goats, crop rotation, terrace riser slicing, trapping, use of forest fodder, 
burning of trash, use of forest soils and black soils and burying of dead animals are executed under the indigenous governance system and practices. Likewise, the making of ponds for water collection and water shade management are major social practices under the governance system, which helps in the conservation of forests as well as keeping the source of water clean. Nevertheless, since the abandoning of existing farmlands began, the practices of the indigenous governance systems have been forgotten or have disappeared. Relationships of trust among farmers, common rules and connectedness among social groups, which were necessary for shaping individual farm activities and creating a unified mountain social landscape, have declined. Furthermore, the use and maintenance of existing infrastructures (temples, schools, shops, banks, health post, micro-finance and other local facilities and so on) have decreased, which in turn further accelerates the loss of people from mountain rural areas or makes it more difficult for middle aged people who wish to return to begin a career in the mountain regions.

\subsection{Farmland Degradation and Eco-Environmental Vulnerability}

An overview of visual observation remarked that terrace damage, gully formation and encroachment of vegetation (grass, shrubs and trees) are caused by the abandonment of traditionally used farmland (Figure 3). The areas where abandonment has taken place, found all the abandoned farmlands $(100 \%)$ have terrace damage; however, the process of plant succession showed little evidence. Regarding the 38 abandoned farmlands observed, 28.9\% (11) suffer from gully formation and mud flows. Only $15.8 \%$ (6) were found with a dominant stage of forest, a well-known successional stage in the re-colonization process of agricultural land following abandonment. A total of $52.6 \%$ (20) abandoned farmlands have advanced stages of tree development dominated by Artocarpus lakoocha, Flemingia congesta, Garuga pinnata, leucaena spp., Iris clarki, Ficus lacor, Ficus semicordata, Ficus hispida, Morus alba, Bauhinia variegate, Cajanus cajan, Litsea monopetala, Bauhinia purpurea, which will eventually create a forest environment. Some of the abandoned farmlands, 7.5\% (3), were already transformed into rock lands. The succession of grasses, shrubs and trees were perceived along the damaged terraces. The greater majority of the abandoned farmlands show a general successional pattern composed of Melia azedarach, Garuga pinnata, Ficus lacor, Litsea monopetala, Acacia catechu, Acer oblongum, Adina cordifolia, Alnus nepalensis, Bauhinia veriegata, Bridelia retusa, Castanea sativa, Castonopsis hystrix, Castonopsis indica, Cedrela toona, Cryptomeria japonica, Dalbergia sissoo, Erythrina variegata, Garuga pinnata, Leucaena leucocephala, Litsea monopetala, Melia azedarach, Lynia ovalifolia, sapium, Rhus succedanca, scima callichi. Figures 3 and 4 show the process of eco-environmental conditions with respect to the overall abandoned farmland.

Farmland abandonment that indicated terrace damage and plant succession in the mountain region of Nepal follow the same fundamental trends commonly described in European mountain areas $[13,38,62]$. This results from general changes in national development and social mobility and have important farmland degradation, threatening environmental and ecological consequences in the mountain region of Nepal. The visual observation in this case study's area allows the authors to reveal some general aspects of abandoned land dynamics such as terrace damage, gully formation, and, naturally, plant succession. Mountain farmland is being more and more marginalized and is declining in this sense. This study's results also show that some abandoned farmlands have been transformed or processed into a dense forest which calls for further investigation to assess the local specific character of this development and to further enhance the understanding of the farmland abandonment process in mountain areas. 


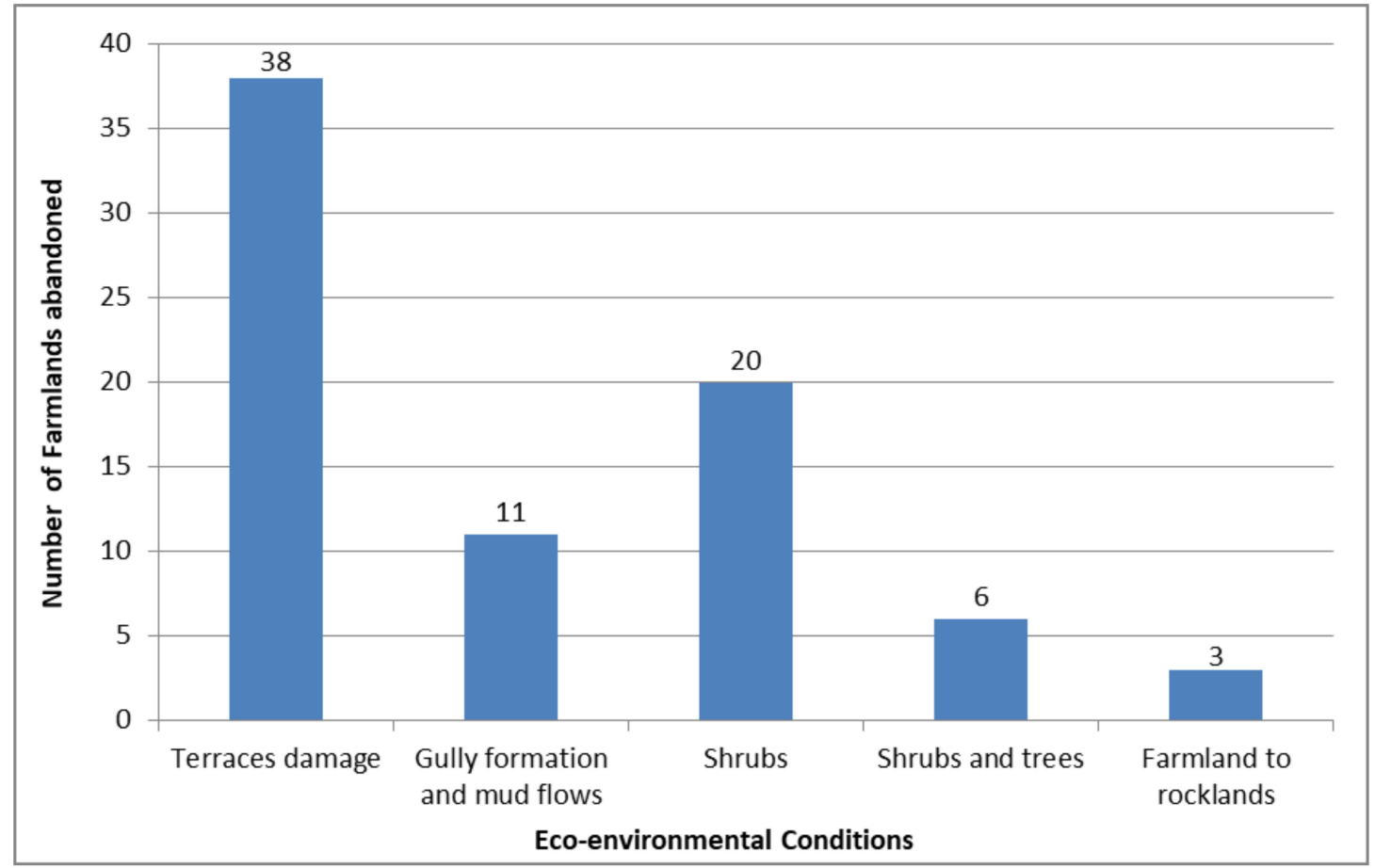

Figure 3. Abandoned farmlands identified with major eco-environmental problems classified into five broad categories.

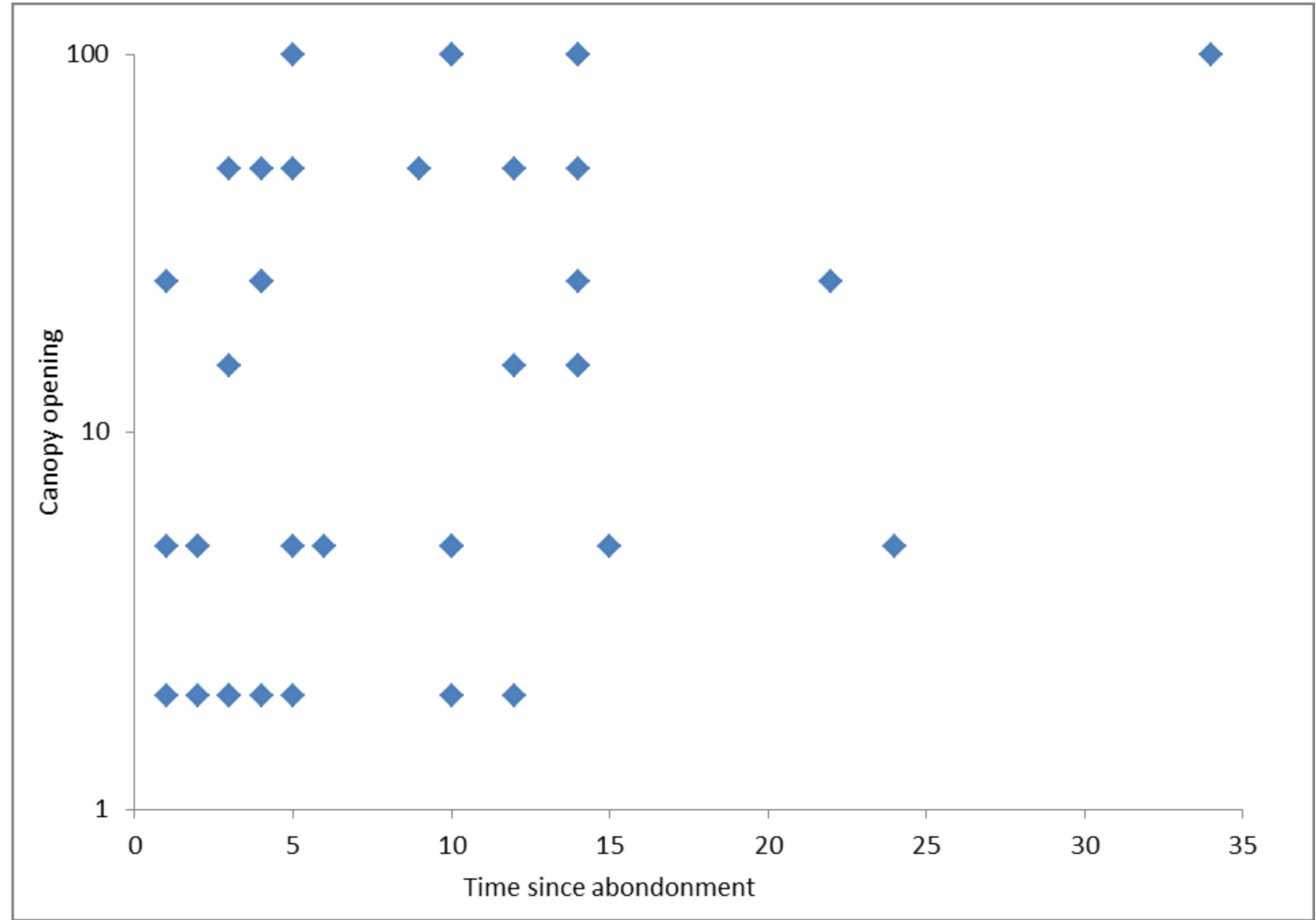

Figure 4. Canopy coverage of plants over different time periods after farmland abandonment.

Over many decades, farmers invested much energy in terrace construction and maintenance as the best means for developing and retaining farmland soils on hill slopes in the mountain 
region [28]. The destruction of terraces not only indicates the losses of one's farmland but also involves the disappearance of one's communal involvement and their roles and practices in the mountain landscape. Abandonment might increase the likelihood of soil loss when terraces are unmaintained [63]. The resultant removal of traditional land management practices (clearing and or terrace formation) almost inevitably leads to ecosystem change, which in turn potentially leads to loss of important biological or cultural values [62]. Ecosystems such as managed farmlands are often very rich in species but these species depend on continued land management to persist, for instance. Once management is removed, other species are able to become dominant and the ecosystem could lose species or be transformed into another ecosystem-type, particularly since forest species are able to establish there [50]. Thus, the ecosystem development after farmland abandonment can be viewed as experiencing degradation because the system is developing away from something that is valued in the community.

The plant succession process after abandonment governs the sustainability of the landscape environment, biodiversity and provision of forest ecosystem services, particularly in the high mountain areas $[3,13,64]$. The authors agree that densely distributed wooded forest, if underused, can contribute to the increase in species habitats and forest products. However, the oldest abandoned farmlands, which the authors believed increased the forest species due to the greater time since abandonment, were not as expected in the study areas. Wherever woody trees were succeeding, their densities were not enough for species habitats. Additionally, farmland abandonment does not automatically lead to plant colonization since terrace damage or landslides take place prior to colonization. Furthermore, the farmlands were intensively used for grazing, thus making favorable conditions for terrace damage, mud flows, soil erosion, leading to increased run-off and damage to the ground level vegetation and grassland ecosystems.

Additionally, the losses of soils somehow lessened after the succession of plants [65]. However, the increasing succession foresees less heterogeneity overall and increased homogenized land cover categories in the basin in the long run. The expansion of unplanted vegetation, especially shrubs on abandoned farmlands, reduced the value of the cultural and aesthetic qualities of the mountain landscape [8]. The changes are welcomed in some cases and in others it is considered as a threat by invasive species [50]. Therefore, in agreement with different assessment studies in mountain regions and scenario analyses $[66,67]$, the future trend is expected to reduce ecosystem diversity in this case study area.

\section{Conclusions}

Abandoned farmlands are extensive over the study area and are expected to further increase in the near future [27]. Farm-based bonds between societies and the mountain landscape reflected significant relationships for ecological, environmental, cultural and aesthetical values [8]. Thus, this study explored in detail the determining driving factors for farmland abandonment and its impact on social systems in the Dordi river basin. Generally, mountain topography, difficulties performing farm activities, low-level farm production, changing farmer lifestyles, lack of household labor, land ownership status, land use obstruction by grazing or nearby forest, invasion of alien species and loss of traditional social life were related to the abandonment of farmland in the mountain areas of Nepal. However, using SPSS analysis, the authors find that mountain road accessibility, farm distance from residence, household size; household head age, Household owner living places, ownership of farmland, salary, business and remittances significantly influenced the abandoning of farmlands throughout the area, although these factors might vary in other areas. This study also revealed that, as a result of abandoning farmland, the mountainous traditional rural landscape and its associated social, cultural norms and values such as "Parma", traditionally managed irrigation systems, water supply systems, social practices, rituals and festive events as well as indigenous local practices were disappearing or less practiced. This means the reduced agricultural systems or full abandonment of farming systems are diminishing the socio-cultural identity as well as the diversity of the whole country. 
Indigenous organization and social practices of mountain communities are counted as major capital for the sustenance of farming as well as cultural activities. A farmer is confident to get the labor and other resources including tools from the neighborhood in a "Parma" situation, as well as help with irrigation canal management activities on a regular basis, all possible due to the inherent endowment of the social system in the mountain communities [28]. Thus, this study's information on traditional practices and changes on the social landscape can provide an important resource in identifying social risks to farmlands from abandonment. Additionally, rapid socio-economic changes in the 21st century have led to significant influence on farmland use and interaction patterns among the people of the mountain region in Nepal $[38,68]$, which ultimately will affect the performance of the social institutions through decision making at various points. Thus, this study suggests that, where there is high potentiality for farmland abandonment, the assessment of farmers' attitudes and preferences, the interdisciplinary of human-environment interactions and of future landscape development that is rooted in the empirical realities of the case study area should be considered.

This study's information on the ecological and environmental patterns in abandoned farmlands displayed a low-level of unplanted vegetation succession. However, it can lead to a wide range of studies providing important insights for the theories of succession and dynamics. The study identified that abandoned farmlands can provide an important outdoor laboratory for observational and experimental studies, while those colonized by dense shrubs can alter the availability of goods and ecosystem services [69,70], or change the status of the basin's biodiversity [71,72], as well as provide opportunities for invasive species [50]. Thus, considering these factors, this research could provide a scientific basis for the design and implementation of further research and/or developing conservation policies throughout the basin.

Finally, this research paper invites researchers and policy makers to think about the future of mountain farmlands and societies where a huge number of mountain people are migrating to enhance their household economy and livelihood security $[47,73,74]$ or seeking to participate in non-farm activities [75]. Regarding this, this study suggests that the valuation of historical land uses and promoting communal management among farmers can be proven to be highly sustainable for the adjustment of mountain slope farmland and human activities. Planting trees or varieties of typical fruits (apples or oranges), or improvement in traditional farming systems could be possible management activities for abandoned farmlands. Additionally, abandoned farmlands might be favorable for herbaceous products such as ginger, turmeric and cardamom, thus, by setting competitive prices for these products, or organizing fairs and markets, they can be promoted for cultivation as well as quality products. This type of farming could be helpful for the maintenance of mountain landscape heterogeneity and the attractiveness thereof for tourism. This also can be the key factor for the maintenance of the social landscape and direct payment for the ecosystem services [76].

Author Contributions: As a part of PhD project, the first author conceptualized the idea, conducts field survey, collected and analyzed data and finalized the manuscript under the direct supervision of second and third author. The fourth, fifth, sixth, seventh eighth and ninth author guided the design of the work and help to finalize the manuscript through regular discussion and critical revisions.

Funding: This research received no external funding.

Acknowledgments: This work is supported by the 135 Strategic Program of the Institute of Mountain Hazard and Environment, Chinese Academy of Sciences (Grant No: SDS-135-1703) and the Chinese Academy of Sciences-the World Academy of Sciences (CAS-TWAS) Presidents Fellowship program for international PhD. We are extremely grateful to Central Department of Geography (CDG) and National Society for Earthquake Technology (NSET), for sharing their valuable datasets and comments. Also, would like to thank International Research on Disaster Risk (IRDR) for providing opportunity to conduct research under young scientist program (YSP). The authors were grateful for the constructive comments from the editor and anonymous reviewers.

Conflicts of Interest: The authors declare no conflict of interest. 


\section{References}

1. Keenleyside, C.; Tucker, G.; McConville, A. Farmland Abandonment in the EU: An Assessment of Trends and Prospects; Institute for European Environmental Policy: London, UK, 2010.

2. Leal Filho, W.; Mandel, M.; Al-Amin, A.Q.; Feher, A.; Chiappetta Jabbour, C.J. An assessment of the causes and consequences of agricultural land abandonment in Europe. Int. J. Sustain. Dev. World Ecol. 2017, 24, 554-560. [CrossRef]

3. MacDonald, D.; Crabtree, J.; Wiesinger, G.; Dax, T.; Stamou, N.; Fleury, P.; Lazpita, J.G.; Gibon, A. Agricultural abandonment in mountain areas of Europe: Environmental consequences and policy response. J. Environ. Manag. 2000, 59, 47-69. [CrossRef]

4. Khanal, N.; Watanabe, T. Abandonment of Agricultural Land and Its Consequences: A Case Study in the Sikles Area, Gandaki Basin, Nepal Himalaya. Mt. Res. Dev. 2006, 26, 32-40. [CrossRef]

5. Campbell, J.E.; Lobell, D.B.; Genova, R.C.; Field, C.B. The global potential of bioenergy on abandoned agriculture lands. Environ. Sci. Technol. 2008, 42, 5791-5794. [CrossRef] [PubMed]

6. Brunner, S.H.; Huber, R.; Grêt-Regamey, A. Mapping uncertainties in the future provision of ecosystem services in a mountain region in Switzerland. Reg. Environ. Chang. 2017, 17, 2309-2321. [CrossRef]

7. Lieskovský, J.; Bezák, P.; Špulerová, J.; Lieskovský, T.; Koleda, P.; Dobrovodská, M.; Bürgi, M.; Gimmi, U. The abandonment of traditional agricultural landscape in Slovakia-Analysis of extent and driving forces. J. Rural Stud. 2015, 37, 75-84. [CrossRef]

8. Antrop, M. The concept of traditional landscapes as a base for landscape evaluation and planning. The example of Flanders Region. Landsc. Urban Plan. 1997, 38, 105-117. [CrossRef]

9. Mottet, A.; Ladet, S.; Coqué, N.; Gibon, A. Agricultural land-use change and its drivers in mountain landscapes: A case study in the Pyrenees. Agric. Ecosyst. Environ. 2006, 114, 296-310. [CrossRef]

10. Mercer, J. Disaster risk reduction or climate change adaptation: Are we reinventing the wheel? J. Int. Dev. 2010, 22, 247-264. [CrossRef]

11. Paton, D. Disaster risk reduction and disaster resilience: progress and challenges. In Disaster Resilience: An Integrated Approach; Charles C Thomas Publisher: Springfield, IL, USA, 2017.

12. Beniston, M. Climatic change in mountain regions: A review of possible impacts. Clim. Chang. 2003, 59, 5-31. [CrossRef]

13. Gellrich, M.; Baur, P.; Koch, B.; Zimmermann, N.E. Agricultural land abandonment and natural forest re-growth in the Swiss mountains: A spatially explicit economic analysis. Agric. Ecosyst. Environ. 2007, 118, 93-108. [CrossRef]

14. Korner, C. Mountain biodiversity, its causes and function: An overview. In Mountain Biodiversity: A Global Assessment; Taylor \& Francis: Didcot, UK, 2002.

15. Schimel, D.; Kittel, T.G.; Running, S.; Monson, R.; Turnipseed, A.; Anderson, D. Carbon sequestration studied in western US mountains. Eos Trans. Am. Geophys. Union 2002, 83, 445-449. [CrossRef]

16. Brooks, P.; Vivoni, E.R. Mountain ecohydrology: Quantifying the role of vegetation in the water balance of montane catchments. Ecohydrology 2008, 1, 187-192. [CrossRef]

17. Locatelli, B.; Lavorel, S.; Sloan, S.; Tappeiner, U.; Geneletti, D. Characteristic trajectories of ecosystem services in mountains. Front. Ecol. Environ. 2017, 15, 150-190. [CrossRef]

18. Fagre, D.B.; Peterson, D.L.; Hessl, A.E. Taking the pulse of mountains: Ecosystem responses to climatic variability. Clim. Chang. 2003, 59, 263-282. [CrossRef]

19. Tasser, E.; Leitinger, G.; Tappeiner, U. Climate change versus land-use change-What affects the mountain landscapes more? Land Use Policy 2017, 60, 60-72. [CrossRef]

20. Tasser, E.; Tappeiner, U. Impact of land use changes on mountain vegetation. Appl. Veg. Sci. 2002, 5, $173-184$. [CrossRef]

21. Genovese, D.; Culasso, F.; Giacosa, E.; Battaglini, L.M. Can Livestock Farming and Tourism Coexist in Mountain Regions? A New Business Model for Sustainability. Sustainability 2017, 9, 2021. [CrossRef]

22. CBS. National Population and Housing Census 2011, National Report; Central Bureau of Statistics (CBS): Kathmandu, Nepal, 2012.

23. DFID/World Bank. Unequal Citizens: Gender, Caste and Ethnic Exclusion in Nepal (Volume 2): Executive Summary (English); Working Paper; DFID/World Bank: Washington, DC, USA, 2011; Volume 2. 
24. Thapa, G.B.; Niroula, G.S. Alternative options of land consolidation in the mountains of Nepal: An analysis based on stakeholders' opinions. Land Use Policy 2008, 25, 338-350. [CrossRef]

25. Manandhar, P. Social Capital and Rural Change: Reflections from the Decade-long Armed Conflict in Nepal. In Contested Development in Nepal: Experiences and Reflections; Heidel Press Pvt Ltd.: Kathmandu, Nepal, 2014; Volume 57, pp. 56-67.

26. Bhattarai, S. The Bola or Parma of the Newar in Manamaiju Village. The Significance of a Farm Labor Exchange System Among Indigenous Peasants in Nepal. Master's Thesis, Universitetet i Tromsø, Tromsø, Norway, 2006.

27. MoAD. Statistical Information on Nepalese Agriculture; Ministry of Agriculture and Development (MoAD): Kathmandu, Nepal, 2014.

28. Paudel, G.S.; Thapa, G.B. Impact of social, institutional and ecological factors on land management practices in mountain watersheds of Nepal. Appl. Geogr. 2004, 24, 35-55. [CrossRef]

29. Ojha, H.R.; Shrestha, K.K.; Subedi, Y.R.; Shah, R.; Nuberg, I.; Heyojoo, B.; Cedamon, E.; Rigg, J.; Tamang, S.; Paudel, K.P. Agricultural land underutilisation in the hills of Nepal: Investigating socio-environmental pathways of change. J. Rural Stud. 2017, 53, 156-172. [CrossRef]

30. Shah, S. Revolution and reaction in the Himalayas: Cultural resistance and the Maoist "New Regime" in western Nepal. Am. Ethnol. 2008, 35, 481-499. [CrossRef]

31. Bellamy, B. Tradition in Transition: Tharu Traditional Governing System in Post-Conflict Nepal; SIT Graduate Institute/SIT Study Abroad: Washington, DC, USA, 2009.

32. LRMP. Land Capability Map; Land Resource Mapping Project (LRMP), Kenting Earth Sciences Limited, Ontario, Canada and Majesty's Government of Nepal: Kathmandu, Nepal, 1986.

33. CARE Nepal. Preliminary Assessment for Piloting Payment for Ecosystem Services in Lamjung; Breifing Document: Kathmandu, Nepal, 2014.

34. MoPE. Nepal National Action Programme (NAP) on Land Degradation and Desertification under the United Nations Conventions to Combat Desertification (UNCCD); Ministry of Population and Environment (MoPE): Kathmandu, Nepal, 2016.

35. UNDP. Nepal Human Development Report 2014:Beyond Geography, Unlocking Human Capital; UNDP: New York, NY, USA, 2014.

36. Meeus, J.H.A.; Wijermans, M.P.; Vroom, M.J. Agricultural landscapes in Europe and their transformation. Landsc. Urban Plan. 1990, 18, 289-352. [CrossRef]

37. Baumann, M.; Kuemmerle, T.; Elbakidze, M.; Ozdogan, M.; Radeloff, V.C.; Keuler, N.S.; Prishchepov, A.V.; Kruhlov, I.; Hostert, P. Patterns and drivers of post-socialist farmland abandonment in Western Ukraine. Land Use Policy 2011, 28, 552-562. [CrossRef]

38. Benayas, J.R.; Martins, A.; Nicolau, J.M.; Schulz, J.J. Abandonment of agricultural land: An overview of drivers and consequences. In CAB Reviews: Perspectives in Agriculture, Veterinary Science, Nutrition and Natural Resources; CABI Publishing: Oxfordshire, UK, 2007; Volume 2, pp. 1-14.

39. Prishchepov, A.V.; Müller, D.; Dubinin, M.; Baumann, M.; Radeloff, V.C. Determinants of agricultural land abandonment in post-Soviet European Russia. Land Use Policy 2013, 30, 873-884. [CrossRef]

40. Molinillo, M.; Lasanta, T.; García-Ruiz, J.M. RESEARCH: Managing Mountainous Degraded Landscapes After Farmland Abandonment in the Central Spanish Pyrenees. Environ. Manag. 1997, 21, 587-598. [CrossRef]

41. Pointereau; Coulon, F.; Girard, P.; Lambotte, M.; Stuczynski, T.; Sánchez Ortega, V.; Del Rio, A. Analysis of Farmland Abandonment and the Extent and Location of Agricultural Areas That Are Actually Abandoned or Are in Risk to Be Abandoned; Joint Research Centre/European Commission/Institute of Environment and Sustainability (IES), Office for Official Publications of the European Communities: Luxembourg, 2008.

42. Nguyen, T.T.; Nguyen, L.D.; Lippe, R.S.; Grote, U. Determinants of Farmers' Land Use Decision-Making: Comparative Evidence From Thailand and Vietnam. World Dev. 2017, 89, 199-213. [CrossRef]

43. Cameron, M.M. Transformations of gender and caste divisions of labor in rural Nepal: Land, hierarchy and the case of untouchable women. J. Anthropol. Res. 1995, 51, 215-246. [CrossRef]

44. Alomia-Hinojosa, V.; Speelman, E.N.; Thapa, A.; Wei, H.-E.; McDonald, A.J.; Tittonell, P.; Groot, J.C. Exploring farmer perceptions of agricultural innovations for maize-legume intensification in the mid-hills region of Nepal. Int. J. Agric. Sustain. 2018, 16, 74-93. [CrossRef]

45. Iheke, O.R.; Aniocha, C.M. Migrant Remittances, Savings and Investments Among Rural Farm Households in Abia State, Nigeria. J. Nutr. Ecol. Food Res. 2017, 4, 28-33. 
46. Maduekwe, N.I.; Adesina, F. Remittances economy, remittances landscape: An analysis of the economic and socioecological implications of remittances to households in South Eastern Nigeria. GeoJournal 2017, 82, 139-155. [CrossRef]

47. ILO. Labour Migration for Employment; A Status Report for Nepal: 2014/2015; International Labor Organization (ILO) and Ministry of Labor and Employment, Government of Nepal: Kathmandu, Nepal, 2014/15.

48. Pradhan, R.; Shrestha, A. Ethnic and Caste Diversity: Implications for Development. 2005. Available online: https:/ / www.adb.org/sites/default/files/publication/28686/wp4.pdf (accessed on 2 July 2018).

49. Thapa, G.B.; Paudel, G.S. Evaluation of the livestock carrying capacity of land resources in the Hills of Nepal based on total digestive nutrient analysis. Agric. Ecosyst. Environ. 2000, 78, 223-235. [CrossRef]

50. Zhang, L.; Jiang, Z. Unveiling the status of alien animals in the arid zone of Asia. PeerJ 2016, 4, e1545. [CrossRef] [PubMed]

51. Zagaria, C.; Schulp, C.J.; Kizos, T.; Verburg, P.H. Perspectives of farmers and tourists on agricultural abandonment in east Lesvos, Greece. Reg. Environ. Chang. 2018, 18, 1467-1479. [CrossRef]

52. Fjellstad, W.; Dramstad, W.E. Patterns of change in two contrasting Norwegian agricultural landscapes. Landsc. Urban Plan. 1999, 45, 177-191. [CrossRef]

53. Fischer, J.; Hartel, T.; Kuemmerle, T. Conservation policy in traditional farming landscapes. Conservat. Lett. 2012, 5, 167-175. [CrossRef]

54. Fortier, J. Nepalese indigenous labour relations. Contrib. Nepal. Stud. 1993, 20, 105-118.

55. Pradhan, P.; Yoder, R. Irrigation Development: The Management and Use of Irrigation in the Mountains of Nepal; ICIMOD: Patan, Nepal, 1990.

56. Groenfeldt, D. Building on tradition: Indigenous irrigation knowledge and sustainable development in Asia. Agric. Hum. Values 1991, 8, 114-120. [CrossRef]

57. Merz, J.; Nakarmi, G.; Weingartner, R. Potential solutions to water scarcity in the rural watersheds of Nepal's Middle Mountains. Mt. Res. Dev. 2003, 23, 14-18. [CrossRef]

58. Ives, J. Himalayan Perceptions: Environmental Change and the Well-Being of Mountain Peoples; Routledge: Abingdon, UK, 2004.

59. Bista, D.B. People of Nepal; Ajanta Pustak Bhandar: Hanumangarh, India, 1980.

60. Berreman, G.D. Peoples and Cultures of the Himalayas. Asian Surv. 1963, 3, 289-304. [CrossRef]

61. Dong, S.; Lassoie, J.; Yan, Z.; Sharma, E.; Shrestha, K.; Pariya, D. Indigenous rangeland resource management in the mountainous areas of northern Nepal: A case study from the Rasuwa District. Rangel. J. 2007, 29, 149-160. [CrossRef]

62. Queiroz, C.; Beilin, R.; Folke, C.; Lindborg, R. Farmland abandonment: Threat or opportunity for biodiversity conservation? A global review. Front. Ecol. Environ. 2014, 12, 288-296. [CrossRef]

63. Seeger, M.; Ries, J. Soil degradation and soil surface process intensities on abandoned fields in Mediterranean mountain environments. Land Degrad. Dev. 2008, 19, 488-501. [CrossRef]

64. Romero-Díaz, A.; Ruiz-Sinoga, J.D.; Robledano-Aymerich, F.; Brevik, E.C.; Cerdà, A. Ecosystem responses to land abandonment in Western Mediterranean Mountains. Catena 2017, 149, 824-835. [CrossRef]

65. El Kateb, H.; Zhang, H.; Zhang, P.; Mosandl, R. Soil erosion and surface runoff on different vegetation covers and slope gradients: A field experiment in Southern Shaanxi Province, China. Catena 2013, 105, 1-10. [CrossRef]

66. Zhou, P.; Luukkanen, O.; Tokola, T.; Nieminen, J. Effect of vegetation cover on soil erosion in a mountainous watershed. Catena 2008, 75, 319-325. [CrossRef]

67. Finlayson, M.; Cruz, R.; Davidson, N.; Alder, J.; Cork, S.; de Groot, R.; Lévêque, C.; Milton, G.; Peterson, G.; Pritchard, D. Millennium Ecosystem Assessment: Ecosystems and Human Well-Being: Wetlands and Water Synthesis; Island Press: Washington, DC, USA, 2005.

68. Subedi, M. Traditions in research on society, culture and health in Nepal. In State, Society and Health in Nepal, Nepal and Himalayan Studies; Routledge 711 Third Avenue: New York, NY, USA, 2018; pp. 1-20.

69. Benayas, J.M.R.; Bullock, J.M.; Newton, A.C. Creating woodland islets to reconcile ecological restoration, conservation and agricultural land use. Front. Ecol. Environ. 2008, 6, 329-336. [CrossRef]

70. Haddaway, N.R.; Styles, D.; Pullin, A.S. Evidence on the environmental impacts of farm land abandonment in high altitude/mountain regions: A systematic map. Environ. Evid. 2014, 3, 17. [CrossRef]

71. Navarro, L.M.; Pereira, H.M. Rewilding abandoned landscapes in Europe. Ecosystems 2012, 15, 900-912. [CrossRef] 
72. Otero, I.; Marull, J.; Tello, E.; Diana, G.; Pons, M.; Coll, F.; Boada, M. Land abandonment, landscape and biodiversity: Questioning the restorative character of the forest transition in the Mediterranean. Ecol. Soc. 2015, 20, 7. [CrossRef]

73. Filipski, M.J.; Van Asselt, J.; Nischan, U.; Belton, B.; Htoo, K.; Win, M.T.; Hein, A.; Kham, L.S.; Naing, Z.M.; Payongayong, E. Rural Livelihoods in Mon State: Evidence from a Representative Household Survey; International Food Policy Research Institute (IFPRI): Washington, DC, USA, 2017.

74. Sikder, M.J.U.; Higgins, V.; Ballis, P.H. Conclusion: Remittances and Household Social Resilience. In Remittance Income and Social Resilience among Migrant Households in Rural Bangladesh; Springer: Berlin, Germany, 2017; pp. 217-225.

75. Gämperli Krauer, U.; Wymann von Dach, S.; Bieri, S. Mountain Women's Future; Issue Brief on Sustainable Mountain Development: Bern, Switzerland, 2017.

76. Nassauer, J.I. Using cultural knowledge to make new landscape patterns. In Issues in Landscape Ecology; Cambridge University Press: Cambridge, UK, 2005; pp. 274-280.

(C) 2018 by the authors. Licensee MDPI, Basel, Switzerland. This article is an open access article distributed under the terms and conditions of the Creative Commons Attribution (CC BY) license (http:// creativecommons.org/licenses/by/4.0/). 